\title{
DROUGHT TOLERANCE IN INTERVARIETAL MAIZE HYBRIDS ${ }^{1}$
}

\author{
DANIEL SARTO ROCHA ${ }^{2}$, CINTHIA SOUZA RODRIGUES ${ }^{2} *$ PAULO BOLLER GALLO ${ }^{3}$, MARCELO TICELLI $^{4}$, \\ MARIA ELISA AYRES GUIDETTI ZAGATTO PATERNIANI ${ }^{2}$
}

\begin{abstract}
In the period of planting of second-season maize, there is high climatic instability with greater probability of occurrence of water deficit. This is one of the factors that most cause reduction in maize grain yield. In this context, the aim was to identify stable, irrigation-responsive and drought-tolerant maize genotypes. The experiments were conducted in Mococa / SP and Tatuí / SP, at Instituto Agronômico, in two assays, one under full irrigation conditions and the other under water stress. The experimental design was randomized blocks with 3 replicates. Male flowering, female flowering, plant height, ear height, hectoliter weight, one hundred grain weight and grain yield were evaluated. Joint analysis of variance and stability analysis were performed by the GGEBiplot method. Significant genotype and site effects were observed for all traits. Significant effects of genotype $\mathrm{x}$ site interaction were found for all traits except ear height and male flowering. The characteristics most affected by water deficit were male flowering, plant and ear heights and grain yield. Genotypes $\mathrm{F}_{2}$ BM709 x PopTol 2, IAC 46 x PopTol 2, F 2 30K75 x PopTol 3 and F2 BM709 x PopTol 3 are considered ideotypes because of their high grain yield, phenotypic plasticity and drought tolerance.
\end{abstract}

Keyword: Water deficit. GGE Biplot. Genotype x environment interaction.

\section{TOLERÂNCIA AO DÉFICIT HÍDRICO EM HÍBRIDOS INTERVARIETAIS DE MILHO}

RESUMO - Na época do plantio de milho safrinha ocorre maior instabilidade climática, com maior probabilidade de ocorrência de períodos de déficit hídrico. Este é um dos fatores que mais causa redução na produtividade de grãos de milho. $\mathrm{O}$ objetivo deste trabalho foi identificar genótipos de milho tolerantes ao déficit hídrico, estáveis e responsivos à irrigação. Avaliaram-se 26 híbridos intervarietais convencionais de milho, em experimentos realizados em Mococa/SP e Tatuí/SP, no Instituto Agronômico. Em cada local foram conduzidos dois ensaios, um sob condições de irrigação e outro sob estresse hídrico, em delineamento experimental de blocos casualizados com 3 repetições. Foram avaliados: florescimentos masculino e feminino, alturas da planta e de espiga, peso hectolítrico, peso de cem grãos e produtividade de grãos. Foi realizada análise de variância conjunta e a estabilidade foi analisada pelo GGEBiplot. Observaram-se efeitos de genótipos e local significativos para todas as características e efeitos significativos da interação genótipos $\mathrm{x}$ locais, exceto para altura de espiga e florescimento masculino. Já o efeito de condições hídricas foi significativo para a maioria dos caracteres, fato essencial para a viabilidade do trabalho. As características mais afetadas pelo déficit hídrico foram florescimento masculino, altura de plantas e de espigas e a produtividade de grãos. Os híbridos $F_{2}$ BM709 x PopTol 2, IAC 46 x PopTol 2, F 2 30K75 x PopTol 3 e F2 BM709 x PopTol 3 são considerados ideótipos por apresentarem elevada produtividade, plasticidade fenotípica e tolerância à seca, podendo ser indicados para programas de melhoramento genético visando tolerância à seca.

Palavras-chave: Déficit hídrico. GGE Biplot. Interação genótipos x ambientes.

\footnotetext{
${ }^{*}$ Corresponding author

${ }^{1}$ Received for publication in $12 / 20 / 2019$; accepted in $08 / 31 / 2020$.

Paper extracted from the doctoral thesis of the first author.

${ }^{2}$ Instituto Agronômico, Campinas, SP, Brazil; sarto.rocha@gmail.com - ORCID: 0000-0002-0305-857X, cinthia.rodrigues@iac.sp.gov.br - ORCID: 0000-0002-0470-561X, elisa@iac.sp.gov.br-ORCID: 0000-0002-1310-8761.

${ }^{3}$ Agência Paulista de Tecnologia dos Agronegócios, Mococa, SP, Brazil; paulogallo.iac.sp.gov.br - ORCID: 0000-0001-6696-0627.

${ }^{4}$ Unidade de Pesquisa e Desenvolvimento de Tatuí, Instituto Agronômico, Tatuí, SP, Brazil; updtatui@iac.sp.gov.br - ORCID: 0000-00030751-6512.
} 


\section{INTRODUCTION}

In Brazil, the planted area of late-season maize surpassed the area of the summer season. The maize planting system during the second season is subject to greater climatic instability with higher probability of occurrence of water deficit periods, since the late-season maize encompasses the end of the rainy season (SCHLICHTING et al., 2014). Water stress is a problem that affects approximately $45 \%$ of agricultural areas and is the largest global restriction on yield, becoming a major problem (MADABULA et al., 2016). In maize, water deficit causes major damage to plant development, reducing grain yield up to $100 \%$.

The primary consequence of water deficit is the stomatal closure that occurs with the decrease in leaf water potential, which invariably coincides with the reduction of photosynthesis and transpiration. According to Zhao et al. (2018), when water stress occurs during vegetative stages, it reduces plant height, leaf expansion and shoot dry mass compared to well-irrigated plants. Maize yield may be affected even in climatically favorable years, if water deficit occurs in the critical period of crop development. Water stress may delay or even paralyze vegetative growth, as well as delaying the reproductive development of plants (TARDIEU; SIMONNEAU; MULLER, 2018). If water stress advances to the reproductive stage, there may be inhibition of flowering, failures in fertilization and abortion of embryos, consequently reducing grain production. According to Pias et al. (2017), a more pronounced effect of water deficit on grain production occurs in the tasseling stage than in the grain filling period, which is called the critical period of the crop.

Given the problems caused by water deficit and the prospect that genetic improvement can overcome them, the need for greater efforts in the development of cultivars tolerant to water deficit is noticeable (TUBEROSA, 2012).

The development of water deficit-tolerant hybrids faces key problems such as: difficulty in obtaining productive genotypes under water deficit due to lower genetic variance in comparison to environmental variance; association of the low production potential of hybrids with tolerance to water deficit; and genotypes $\mathrm{x}$ environments interaction, which hinders the selection of genotypes with high grain yield. According to Derera, Tongoona and vivek (2008), the search for water deficit-tolerant hybrids can be discouraged by a perception that water deficit-tolerant genotypes may have low yield in stress-free environments, indicating that there is a penalty on yield under optimal conditions (MORENO; LUMBRERAS;
PAGES, 2005).

Thus, water stress-tolerant hybrids can be obtained through the cross of water deficit-tolerant strains with strains that were selected for high general combining capacity in favorable environments, which may possibly result in hybrids with tolerance to water deficit and high grain yield in non-restrictive environments (DERERA; TONGOONA; VIVEK, 2008). Thus, the main focus of the improvement should be the increase in grain yield under water deficit conditions without penalizing the production potential under favorable conditions, which is relevant given the unpredictability of the drought periods (RIBAUT et al., 2009).

Despite the difficulty in selecting water deficit-tolerant genotypes, it is important to use information on performance with and without water stress because, as already mentioned, genotypes selected under stress may show a low production potential under favorable conditions (ZIYOMO; BERNARDO, 2013). In addition, it is essential to identify water deficit-tolerant genotypes with a high production potential and that have wide adaptability and stability. In this context, the use of methodologies to study the genotypes $\mathrm{x}$ environments interaction may result in more accurate selection of genotypes more tolerant to water deficit and more responsive to adequate water conditions. Several methods have been proposed to evaluate adaptability and production stability when there is interaction between genotypes and environments. The GGE Biplot methodology is very useful for studying performance patterns in genotypes according to the environment and making predictions about the average performance of genotypes in specific environments (KARIMIZADEH et al., 2013).

The hybrid from cross between $\mathrm{F}_{2}$ populations may represent an alternative of hybrid seed with affordable prices, good genetic potential and high grain yield, ideal for small and medium producers (GUIMARÃES et al., 2014). Obtaining seeds from these hybrids is simplified because the stages of production and multiplication of strains are eliminated from the process. Despite the importance of these hybrids called intervarietal, studies on performance for tolerance to water deficit are scarce, which highlights the importance of this study. The objectives were to evaluate intervarietal hybrids of maize from a $13 \times 2$ half-diallel, identify genotypes with higher yield and stability, responsive to irrigation and tolerant to water deficit, aiming to obtain new hybrids for the seed market and new sources of tolerance for breeding programs. 


\section{MATERIAL AND METHODS}

Intervarietal hybrids were obtained using a $13 \times 2$ half-diallel. Group 1 consisted of thirteen genotypes, formed by twelve populations of $F_{2}$ generations of commercial hybrids and one variety of commercial open pollination; group 2 consisted of two populations tolerant to water deficit, Pop Tol 2 and Pop Tol 3, which were planted in two blocks with 10-meter-long rows and at planting density of five plants per meter. Manual crosses were performed using a mixture of pollen of each tester (group 2) to pollinate ears of $F_{2}$ populations. The populations were selected with information from the companies that developed the hybrids and also information from the regional trials conducted by Instituto Agronômico/IAC.

In the second season of 2017, the 26 intervarietal hybrids obtained from the $13 \times 2$ halfdiallel, together with the 13 populations of group 1 , two testers and three controls: IAC 8046, AS1633 PRO2, DKB290 PRO3, were evaluated (Table1).

Table 1. Description of the parental populations of maize used in the $13 \times 2$ half-diallel.

\begin{tabular}{|c|c|c|c|c|c|c|}
\hline \multirow[b]{2}{*}{ Genotypes } & \multirow[b]{2}{*}{ Denomination } & \multirow[b]{2}{*}{ Origin } & \multicolumn{4}{|c|}{ Characteristics of the commercial hybrid } \\
\hline & & & Type & Grain Type & Grain Color & Cycle \\
\hline \multicolumn{7}{|l|}{ Group 1} \\
\hline $\mathrm{F}_{2} \mathrm{AG} 8088$ & P1 & Monsanto & $\mathrm{SH}$ & Hard & Orangish & Early \\
\hline $\mathrm{F}_{2} \mathrm{AG} 8060$ & $\mathrm{P} 2$ & Monsanto & SH & Hard & Orangish & Early \\
\hline $\mathrm{F}_{2} 30 \mathrm{~F} 90$ & P3 & Pioneer & SH & Hard & Yellow & Early \\
\hline $\mathrm{F}_{2} 30 \mathrm{~F} 53$ & P4 & Pioneer & $\mathrm{SH}$ & Semi-hard & Orangish & Early \\
\hline $\mathrm{F}_{2} \mathrm{DKB} 350$ & P5 & Monsanto & $\mathrm{TH}$ & Hard & Orangish & Early \\
\hline $\mathrm{F}_{2} 30 \mathrm{~K} 75$ & P6 & Pioneer & $\mathrm{mSH}$ & Semi-hard & Orangish & Semi-early \\
\hline $\mathrm{F}_{2} 30 \mathrm{~S} 31$ & P7 & Pioneer & SH & Semi-hard & Orangish & Semi-early \\
\hline $\mathrm{F}_{2} \mathrm{BM} 709$ & P8 & Biomatrix & SH & Semi-dent & Reddish & Semi-early \\
\hline IAC 46 & P9 & IAC & SH & Semi-dent & Orangish & Early \\
\hline AL Bandeirantes & $\mathrm{P} 10$ & CATI & $\mathrm{V}$ & Semi-hard & Yellow Orangish & Semi-early \\
\hline $\mathrm{F}_{2} \mathrm{DKB} 390$ & P11 & Monsanto & SH & Hard & Yellow Orangish & Early \\
\hline $\mathrm{F}_{2}$ Maximus & $\mathrm{P} 12$ & Syngenta & SH & Hard & Orangish & Early \\
\hline $\mathrm{F}_{2} \mathrm{FT} 510$ & $\mathrm{P} 13$ & FT & SH & Hard & Orangish & Early \\
\hline \multicolumn{7}{|l|}{ Group 2} \\
\hline Population Tolerant 2 & $\mathrm{~T} 1$ & IAC & Pop & Semi-dent & Orangish & Early \\
\hline Population Tolerant 3 & $\mathrm{~T} 2$ & JMen & Pop & Semi-hard & Orangish & Early \\
\hline
\end{tabular}

SH: single hybrid; TH: triple hybrid; mSH: modified single hybrid; V: variety; Pop: population.

The experiments were conducted under a randomized block design with three replicates in two locations in the state of São Paulo, Brazil: Mococa and Tatuí. In each site, one experiment was irrigated throughout the cycle and the other was subjected to water stress, with suspension of irrigation in the reproductive stage, prior to flowering. The assay subjected to water stress received water only to establish the plants. During the experiment, total precipitation was around $559.2 \mathrm{~mm}$ in Mococa and about $655.8 \mathrm{~mm}$ in Tatuí (Figure 1). The climatic data is presented by 10 -day period and the method of Thornthwaite (1948) was used to calculate potential evapotranspiration in the late season period of 2017 for the two sites.

The plots consisted of two 5-m-long rows at spacing of $0.6 \mathrm{~m}$ between rows and $0.25 \mathrm{~m}$ between plants, in Mococa. In Tatuí, the plots consisted of two 5-m-long rows at spacing of $0.8 \mathrm{~m}$ between rows and $0.2 \mathrm{~m}$ between plants. Thinning was carried out 20 days after emergence in all experiments, leaving 20 plants per row in Mococa and 25 plants per row in Tatuí. The other cultural practices used in the experiments were the same as those recommended for maize crop in the evaluation regions.

The characteristics evaluated were: male flowering (MF): number of days necessary for $50 \%$ of the plants in the plot to be at anthesis, from the date of planting; female flowering (FF): number of days necessary for $50 \%$ of the plants in the plot to have the style-stigma formed, from the date of planting; plant height $(\mathrm{PH})$ and ear insertion height $(\mathrm{EH})$ : obtained by the measurement taken from the soil level to the insertion of the flag leaf and the main ear in five plants of the plot, respectively, in meters; hectoliter weight (HW): measurement of the weight of a volume of grains, determined by a hectoliter scale with capacity of $1 / 4$ liter, in $\mathrm{kg} / \mathrm{hL}$; hundred-grain weight (HGW): measurement of the weight of 100 grains, in grams; grain yield (GY): measured in $\mathrm{kg} / \mathrm{ha}$, adjusted to $13 \%$ moisture content and transformed to $\mathrm{kg} / \mathrm{ha}$ according to the spacing used in each assay. 
Water Balance Extract, Mococa/SP

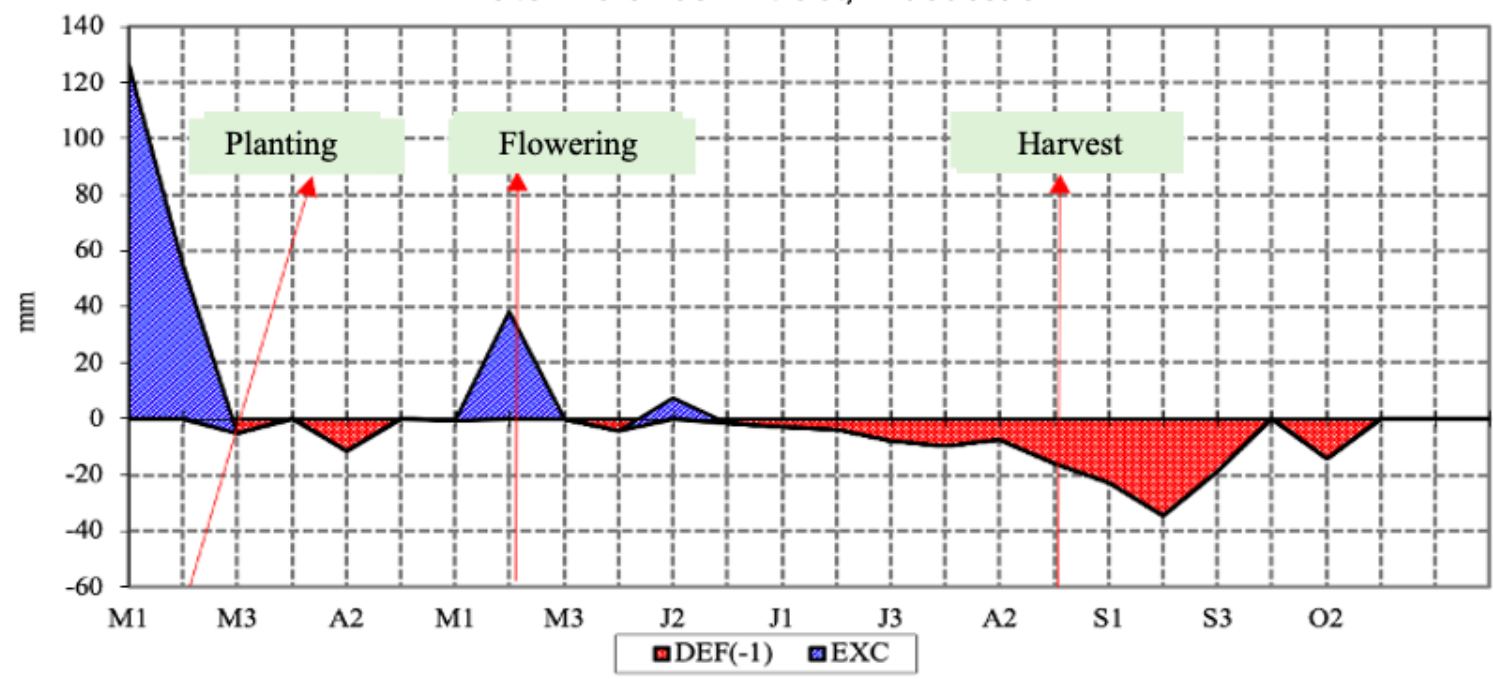

Water Balance Extract, Tatui/SP

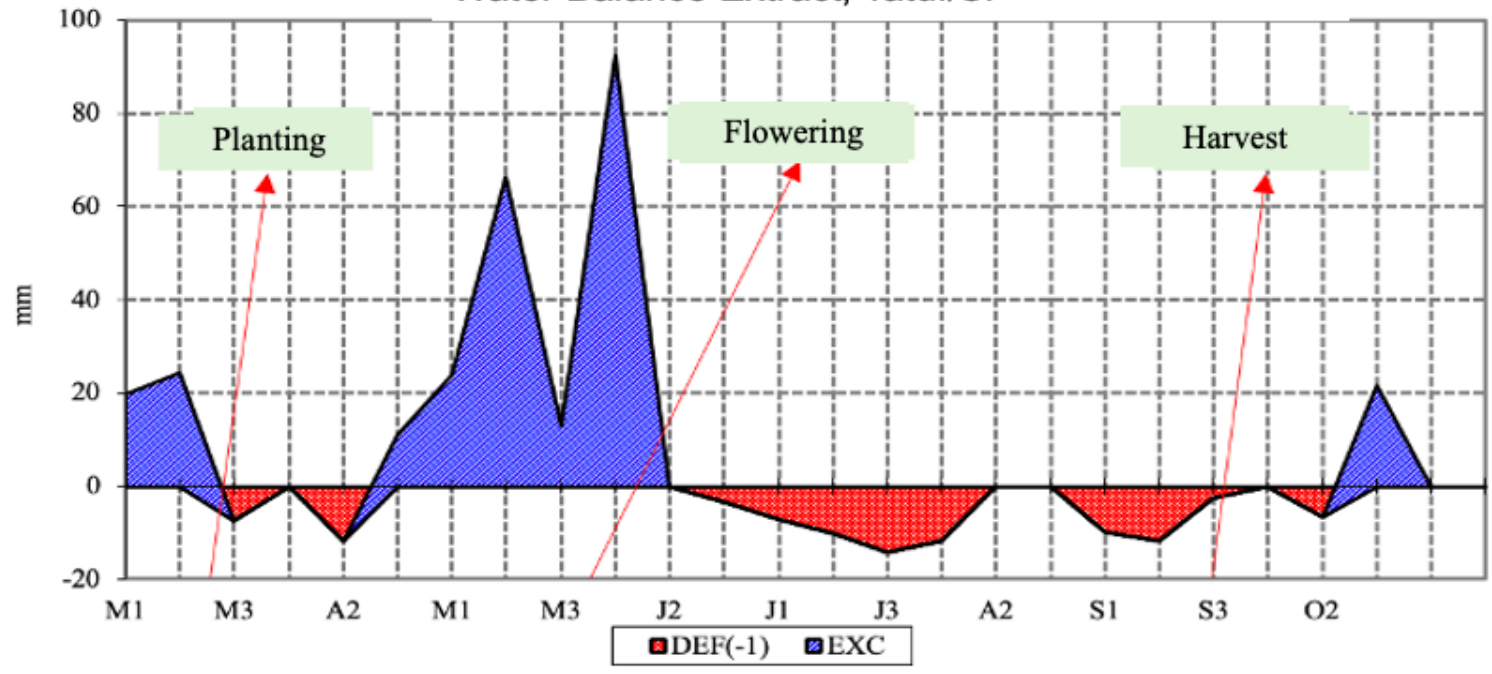

Figure 1. Sequential Water Balance of Thornthwaite \& Mather (1955) for Mococa and Tatuí in 2017 and available water capacity (AWC) of $80 \mathrm{~mm}$.

After data collection, analyses of variance were performed in each environment. The homogeneity of residual variances was tested by Hartley test to perform the joint analysis of variance. Joint analyses were carried out for the experiments conducted in Mococa and Tatuí, following the statistical model:

$$
Y_{i j k l}=\mu+b_{j(k l)}+t_{i}+a_{k}+s_{l}+t a_{i k}+t s_{i l}+a s_{k l}+t a s_{i k l}+e_{i j k l}
$$

where: $Y_{\mathrm{ijkl}}$ is the value corresponding to the ijkl-th observation referring to the i-th genotype, in the $\mathrm{j}$-th block within the $\mathrm{k}$-th water condition and $\mathrm{l}$-th site; $\mu$ is the overall mean; $b_{j(k l)}$ is the effect of the $j$ th block within the $\mathrm{k}$-th condition and l-th site; $t_{i}$ is the effect of the $i$-th genotype; $a_{k}$ is the effect of $k$-th condition; $s_{1}$ is the effect of the l-th site; $\mathrm{ta}_{\mathrm{ik}}$ is the effect of the interaction between genotype and water condition; $\mathrm{ts}_{\mathrm{il}}$ is the effect of the interaction between genotype and site; $\mathrm{as}_{\mathrm{kl}}$ is the effect of the interaction between the water condition and the site; $\operatorname{tas}_{\mathrm{ikl}}$ is the effect of the interaction between the treatment, the condition and the site; $\mathrm{e}_{\mathrm{ijKl}}$ is the effect of the experimental error associated with the observation $\mathrm{Y}_{\mathrm{ijk} \mathrm{k}}$. The means of grain yield were grouped by the Scott and Knott (1974) test at 5\% probability level, using the means of the different variables under the irrigated conditions and the means under the water deficit conditions.

Using the data of the mean grain yield, a graph was constructed to classify the hybrids regarding the response to water deficit. In this graph, the $\mathrm{X}$ axis corresponds to grain yield without stress and the $\mathrm{Y}$ axis corresponds to grain yield under stress conditions. Thus, the hybrids were classified into four groups: TR group contains hybrids that have superior performance under both conditions, with genotypes that are tolerant to stress and 
responsive. The TNR group contains hybrids with relatively higher performance only under stress conditions, with genotypes that are tolerant and nonresponsive. The SNR group is formed by hybrids with below-average performance under both conditions in which the experiments were conducted, being sensitive and non-responsive. The SR group was composed of hybrids that are sensitive and responsive, because they have low yield under stress conditions, but increase their mean as the environmental conditions improve.

In order to identify genotypes more adapted to the four environments and the most stable, analyses of the genotype $\mathrm{x}$ environment interaction were performed by the GGE Biplot method (YAN et al., 2000) through the GGE Biplot GUI package in the R program (FRUTOS; GALINDO; LEIVA, 2014). The model for GGE Biplot analysis is presented below:

$$
Y_{i j}-Y_{J}=\lambda_{1} \xi_{i 1} \eta_{j 1}+\lambda_{2} \xi_{i 2} \eta_{j 2}+\varepsilon_{i j}
$$

where $Y_{i j}$ is the average yield of the genotype $i$ in the environment $j ; Y_{J}$ is the overall mean of the genotypes in the environment $\mathrm{j} ; \lambda_{1}$ and $\lambda_{2}$ are the singular values for PC1 and PC2, respectively; $\xi_{1}$ and $\xi_{2}$ are the scores of the principal components $\mathrm{PC} 1$ and $\mathrm{PC} 2$, respectively, for the genotype $i ; \eta_{1}$ and $\eta_{2}$ are the scores of $\mathrm{PC} 1$ and $\mathrm{PC} 2$, respectively for the environment $j$; and $\varepsilon_{i j}$ is the residual of the model associated with the genotype $i$ in the environment $j$.

\section{RESULTS AND DISCUSSION}

Table 2 presents the joint analyses of variance for all evaluated traits. Estimates of coefficients of variation $(\mathrm{CV})$ indicated experimental accuracy from medium to high for all traits. It is observed that the effect of genotypes was significant $(\mathrm{P}<0.01)$, for all characteristics, indicating that there are differences of performance between hybrids, and it is possible to select genotypes more tolerant to water deficit. There was also a pronounced effect of site $(\mathrm{P}<0.01)$, and it can be affirmed that there were differences between Mococa and Tatuí, i.e., the sites influenced all the evaluated traits. On the other hand, the effect of water conditions was highly significant for most traits (GY, PH, EH, MF, FF, HGW), which was essential for the viability of the study. The effect of the water conditions $\mathrm{x}$ genotypes interaction was significant only for 100-grain weight (HGW). The sites $\mathrm{x}$ genotypes interaction was significant for GY, $\mathrm{PH}, \mathrm{HGW}$ and $\mathrm{HW}$, indicating that the genotypes did not have coincident relative behavior in the different sites. Thus, there is a need for more detailed studies on the interaction of sites $\mathrm{x}$ genotypes, so that it can be interpreted and for the purpose of selecting genotypes that are stable and tolerant to water deficit (Table 2).

Table 2. Joint analysis of variance for grain yield ( $\mathrm{GY}, \mathrm{kg} / \mathrm{ha})$, plant height $(\mathrm{PH}, \mathrm{m})$, ear height $(\mathrm{EH}, \mathrm{m})$, male flowering (MF, days), female flowering (FF, days), 100-grain weight (HGW, g) and hectoliter weight $(\mathrm{HW}, \mathrm{kg} / \mathrm{hL})$ of intervarietal hybrids, parents and controls, under irrigation and under water deficit, in the second season of 2017, in Mococa/SP and Tatuí/SP.

\begin{tabular}{|c|c|c|c|c|c|c|c|c|}
\hline \multirow{2}{*}{ SV } & \multirow{2}{*}{$\mathrm{DF}$} & \multicolumn{7}{|c|}{ MS } \\
\hline & & GY & $\mathrm{PH}$ & $\mathrm{EH}$ & MF & FF & HGW & HW \\
\hline Block/S/WC & 7 & $4300.000^{* *}$ & $0.200^{* * *}$ & $0.021^{* *}$ & $7.001^{* *}$ & $13.000^{* *}$ & $47.002^{* *}$ & $4.200^{* *}$ \\
\hline Site (S) & 1 & $470000.000^{* *}$ & $39.200^{* *}$ & $12.853^{* *}$ & $8305.000^{* *}$ & $6854.000^{* *}$ & $3086.001^{\text {** }}$ & $33.600^{* *}$ \\
\hline Water Cond. (WC) & 1 & $165000.000^{* *}$ & $10.500^{* *}$ & $2.421^{* *}$ & $430.000^{* *}$ & $845.000^{* *}$ & $68.000^{* *}$ & $0.101^{\mathrm{ns}}$ \\
\hline Genotypes (G) & 43 & $18200.000 * *$ & $0.200^{* *}$ & $0.122^{* *}$ & $14.000^{* *}$ & $9.001^{* *}$ & $76.000^{* *}$ & $15.600^{* *}$ \\
\hline S x WC & 1 & $46700.000^{* *}$ & $5.800^{* *}$ & $3.554^{* *}$ & $398.002^{* *}$ & $781.003^{* *}$ & $114.000^{* *}$ & $55.300^{* *}$ \\
\hline $\mathrm{S} \times \mathrm{G}$ & 43 & $2970.000 * *$ & $0.019^{* *}$ & $0.010^{\mathrm{ns}}$ & $3.001^{\mathrm{ns}}$ & $3.000^{*}$ & $11.000^{* *}$ & $3.400^{* *}$ \\
\hline WC x G & 43 & $732.000^{\mathrm{ns}}$ & $0.007^{\mathrm{ns}}$ & $0.010^{\mathrm{ns}}$ & $3.002^{\mathrm{ns}}$ & $1.000^{\mathrm{ns}}$ & $9.000^{*}$ & $1.000^{\mathrm{ns}}$ \\
\hline S x WC x G & 43 & $600.000^{\mathrm{ns}}$ & $0.012^{*}$ & $0.011^{\mathrm{ns}}$ & $5.001^{* *}$ & $2.000^{\mathrm{ns}}$ & $7.001^{\mathrm{ns}}$ & $0.900^{\mathrm{ns}}$ \\
\hline Residual & 301 & 617.000 & 0.009 & 0.010 & 2.000 & 2.001 & 6.000 & 1.100 \\
\hline $\mathrm{CV} \%$ & & 15.9 & 4.1 & 6.5 & 2.1 & 1.8 & 7.2 & 1.4 \\
\hline
\end{tabular}

**, *, ${ }^{\text {ns: }}$ : significant at $0.01 ; 0.05$ and not significant, respectively; SV: source of variation; DF: degrees of freedom; MS: mean square; WC: water conditions.

The variation of the means of the characteristics evaluated under the different water conditions shows the great influence of water stress on the genotypes. Only hectoliter weight (HW) and 100 -grain weight $(\mathrm{HGW})$ showed a small variation in the means, i.e., these characteristics were not affected by the different water conditions (Figure 2). Plants under irrigated conditions grew more, being around $2.37 \mathrm{~m}$ tall, while plants under water stress were on average $2.07 \mathrm{~m}$ tall, that is, under stress 
there was an average reduction of $30 \mathrm{~cm}$ in plant height. Melo et al. (2018), studying maize genotypes subjected to water deficit during the tasseling period, also found lower PH compared to genotypes grown in environment without water deficit. A similar result was also observed for ear height, as there was a reduction of $15 \mathrm{~cm}$ in the main ear height in plants under water stress. This is because water deficit reduces cell size and cell division, which can affect plant height under drought conditions (AHMADIKHAH; MARUFINIA, 2016).

Water deficit increased the number of days for female flowering and male flowering. Maize is a crop with high sensitivity to water stress, especially when stress occurs in the reproductive stage. The greatest levels of damage are observed when water deficit occurs in this stage. Water deficit during this period can inhibit flowering, cause failures in fertility and abortion of embryos, resulting in reduced grain yield (EDMEADES, 2013). According to Durães et al. (2004), only two days of water stress during flowering are able to reduce yield by more than $20 \%$, and four to eight days can cause losses of more than $50 \%$, because it is in this period that grain yield is defined. These results were also confirmed in the present study, since the average grain yield was $5359.79 \mathrm{~kg} \cdot \mathrm{ha}^{-1}$ under the irrigated water regime and $4391.01 \mathrm{~kg} \cdot \mathrm{ha}^{-1}$ under the water deficit regime, i.e., there was a reduction of almost $20 \%$ in grain yield (Figure 2).

Grain yield is a complex character, greatly influenced by the environment, especially water deficit, involves virtually all plant genes and, therefore, depends on the result of the expression of various traits, such as flowering, plant height and grain mass. Due to its importance, grain yield corresponds to the key characteristic in the evaluation and obtaining of genotypes tolerant to water deficit (BERNARDO, 2010). Anjum et al. (2017) evaluated different maize hybrids and observed different performances in response to water deficit, as well as reduced growth and severe losses of yield when water deficit was imposed on the reproductive stage.

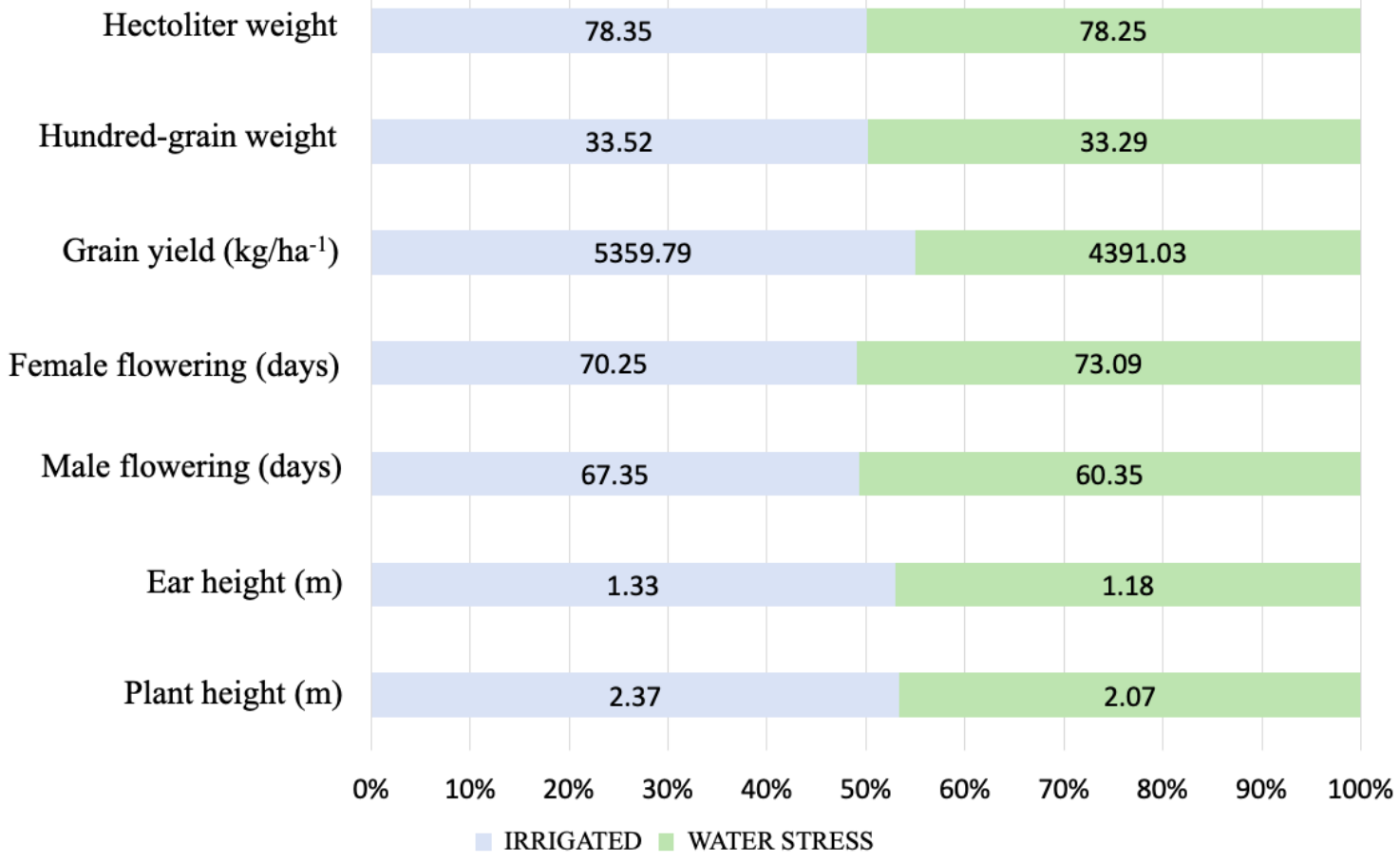

Figure 2. Means of plant height and ear height (m), number of days for female flowering and male flowering, grain yield $(\mathrm{kg} / \mathrm{ha})$, hundred-grain weight and hectoliter weight of maize genotypes in environments without stress (irrigated) and with stress (water deficit).

Figure 3 illustrates the graphical dispersion of grain yield estimates for the classification of genotypes in terms of tolerance and response to water deficit. The hybrids were classified into four groups according to the graph quadrants. The SNR quadrant contains hybrids that did not perform well under both water conditions, being classified as nontolerant and non-responsive. These included the intervarietal hybrids $17\left(\mathrm{~F}_{2}\right.$ 30F53 x PopTol 3), $4\left(\mathrm{~F}_{2}\right.$ 30F53 x PopTol 2), 24 (F2 DKB390 x PopTol 3), 25 $\left(\mathrm{F}_{2}\right.$ Maximus $\mathrm{x}$ PopTol 3) and $13\left(\mathrm{~F}_{2}\right.$ FT510 $\mathrm{x}$ PopTol 2). 
In the TNR quadrant, hybrids are classified as tolerant and non-responsive to environmental improvement, and this quadrant contains the hybrids 15 ( $\mathrm{F}_{2}$ AG8060 x PopTol 3), 22 (IAC $46 \times$ PopTol 3) and 1 ( $F_{2} A G 8088 \times$ PopTol 2), in addition to the control IAC 8046, which performed well in the environment with water deficit, but showed below average yield in irrigated environments. These genotypes can be selected as tolerant parents in breeding programs. The SR quadrant was formed by the hybrids 23 (AL Bandeirantes x PopTol 3), $26\left(\mathrm{~F}_{2}\right.$ FT510 x PopTol 3), 20 ( $\mathrm{F}_{2}$ 30S31 x PopTol 3) and 2 $\left(F_{2}\right.$ AG8060 x PopTol 2), which were not tolerant but showed high average in irrigated environments, and can be recommended for these specific environments. Hybrids with superior average performance under both water conditions, namely 8
( $F_{2}$ BM709 x PopTol 2), 9 (IAC 46 x PopTol 2), 21 $\left(\mathrm{F}_{2}\right.$ BM709 x PopTol 3) and the control DKB 290 PRO3, are represented in the TR quadrant and can be considered tolerant to water deficit and responsive to the improvement of environmental conditions. Among these, hybrid $8\left(\mathrm{~F}_{2}\right.$ BM709 x PopTol 2) showed the best performance, producing on average $7511.6 \mathrm{~kg} \cdot \mathrm{ha}^{-1}$ in the irrigated water regime and $5884.7 \mathrm{~kg} . \mathrm{ha}^{-1}$ in the environment with water deficit (Figure 3).

Regarding tolerance to water deficit, the crosses of $\mathrm{F}_{2}$ populations of the hybrids BM709 and IAC 46 with PopTol 2 and 3 stood out. Thus, the populations of hybrids BM709 and IAC 46 can be used as a source of resistance for tolerance to water deficit in breeding programs.

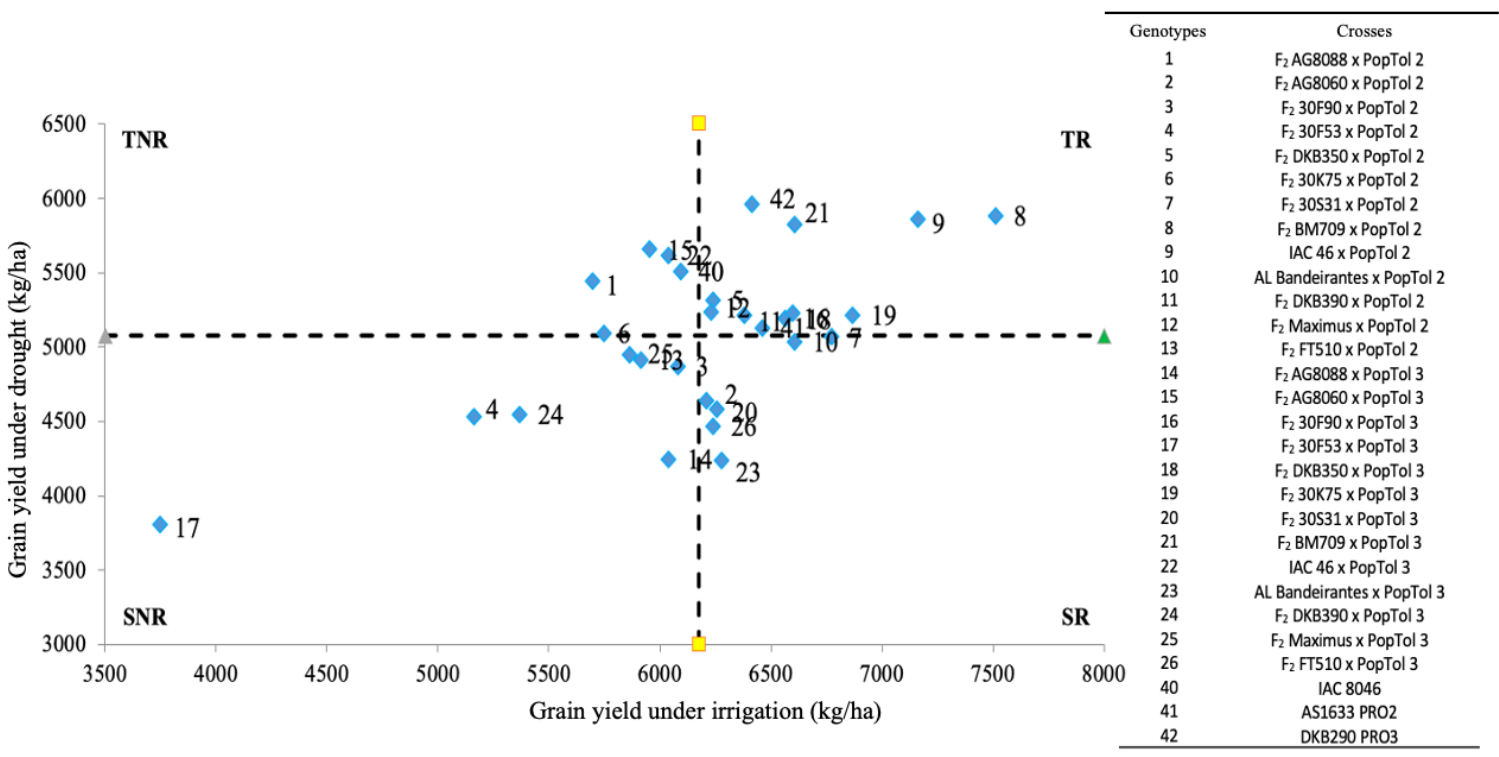

Figure 3. Performance in terms of water deficit tolerance and irrigation response of 26 intervarietal hybrids and 3 controls, for yield in $\mathrm{kg} / \mathrm{ha}$ considering the average of the environments. Numbers 1 to 26 are intervarietal hybrids and the controls 40, 41 and 42. TNR: tolerant and non-responsive; TR: tolerant and responsive; SR: sensitive and responsive and SNR: sensitive and non-responsive.

Identification of genotypes with a high production potential, together with wide adaptability and stability, is a key objective of any maize breeding program. However, the genotypes $\mathrm{x}$ environments interaction is the main obstacle in the selection of genotypes with high potential. The use of tools to study genotypes $\mathrm{x}$ environments interaction can lead to more accurate selection of more drought-tolerant and more responsive genotypes (SSERUMAGA et al., 2018). Considering the average data of grain yield, an important characteristic in the development of water deficittolerant cultivars and that showed greater variation in the present study, adaptability and stability analyses were performed via GGE Biplot. For the first two components, axis 1 explained $42.78 \%$ and axis 2 explained $42.06 \%$ of the variation, for grain yield, and together they explained $84.84 \%$ of the sum of squares due to the $\mathrm{G}+\mathrm{GxE}$ effects (Figures 4 and 5).

The vector view of the GGE-biplot (Figure 4) provides a succinct summary of the interrelations between environments. The vectors of the environments (in red) show that the interrelation between Mococa irrigated and Mococa under water deficit is positive, because the angle formed between the vectors is less than $90^{\circ}$. The environments of Tatuí with and without stress also showed a positive correlation. Mococa environments are also positively correlated with the Tatuí environment under water deficit. However, between the contrasting environments of Mococa and the irrigated environment of Tatuí, the angle formed is greater than $90^{\circ}$, so they are negatively correlated. Hybrids adapted to or with high yield in Mococa (water 
deficit) may show a similar response to the Tatuí environment (water deficit), and it is possible to perform indirect selection for the irrigated Mococa environment. However, the opposite occurs in the environment with satisfactory water conditions in
Tatuí, that is, genotypes tolerant to water deficit do not respond well to irrigation in Tatuí. Therefore, it is important to evaluate genotypes tolerant to water deficit in several sites with different water conditions.

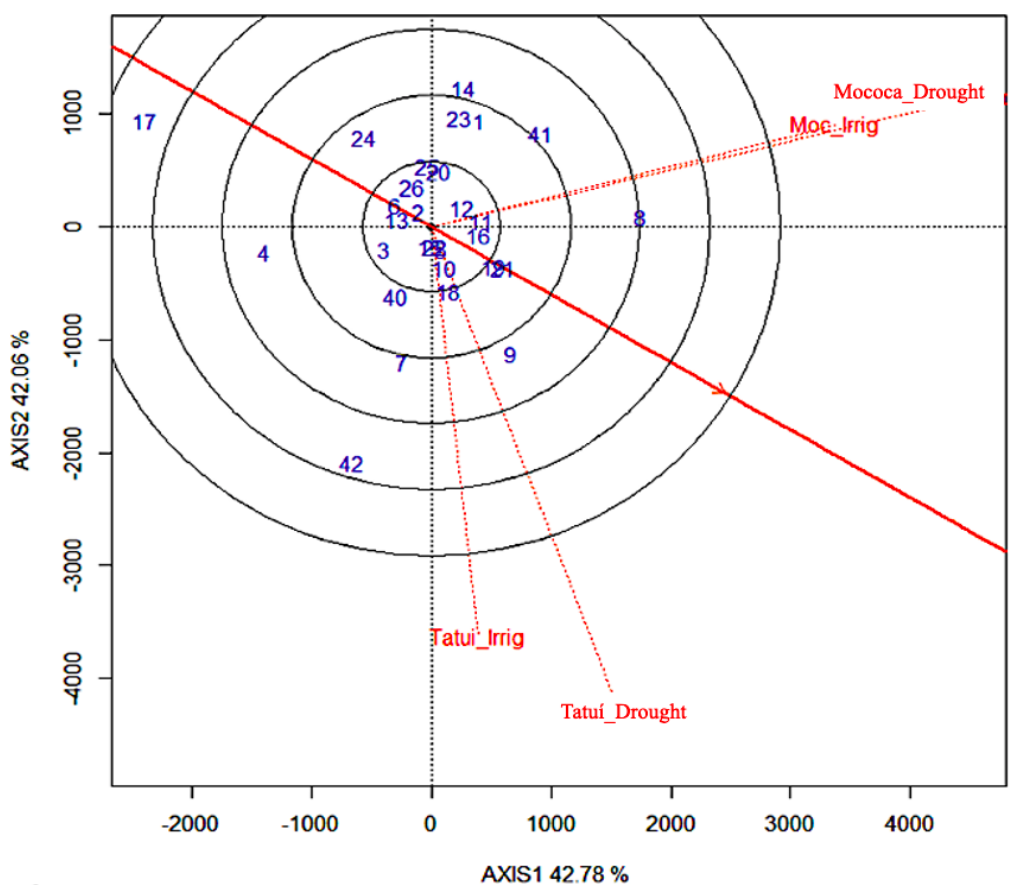

\begin{tabular}{cc} 
Genotypes & Crosses \\
\hline 1 & $F_{2}$ AG8088 $\times$ PopTol 2 \\
2 & $F_{2}$ AG8060 $\times$ PopTol 2 \\
3 & $F_{2}$ 30F90 $\times$ PopTol 2 \\
4 & $F_{2}$ 30F53 $\times$ PopTol 2 \\
5 & $F_{2}$ DKB350 $\times$ PopTol 2 \\
6 & $F_{2}$ 30K75 $\times$ PopTol 2 \\
7 & $F_{2}$ 30S31 $\times$ PopTol 2 \\
8 & $F_{2}$ BM709 $\times$ PopTol 2 \\
9 & $F_{2}$ IAC 46 $\times$ PopTol 2 \\
10 & $F_{2}$ AL Bandeirantes $\times$ PopTol 2 \\
11 & $F_{2}$ DKB390 $\times$ PopTol 2 \\
12 & $F_{2}$ Maximus $\times$ PopTol 2 \\
13 & $F_{2}$ FT510 $\times$ PopTol 2 \\
14 & $F_{2}$ AG8088 $\times$ PopTol 3 \\
15 & $F_{2}$ AG8060 $\times$ PopTol 3 \\
16 & $F_{2}$ 30F90 $\times$ PopTol 3 \\
17 & $F_{2}$ 30F53 $\times$ PopTol 3 \\
18 & $F_{2}$ DKB350 $\times$ PopTol 3 \\
19 & $F_{2}$ 30K75 $\times$ PopTol 3 \\
20 & $F_{2}$ 30S31 $\times$ PopTol 3 \\
21 & $F_{2}$ BM709 $\times$ PopTol 3 \\
22 & $F_{2}$ IAC 46 $\times$ PopTol 3 \\
23 & $F_{2}$ AL Bandeirantes $\times$ PopTol 3 \\
24 & $F_{2}$ DKB390 $\times$ PopTol 3 \\
25 & $F_{2}$ Maximus $\times$ PopTol 3 \\
26 & $F_{2}$ FT510 $\times$ PopTol 3 \\
40 & IAC 8046 \\
41 & AS1633 PRO2 \\
42 & DKB290 PRO3 \\
\hline &
\end{tabular}

Figure 4. Graphic representation of the interrelation of the tested environments with emphasis on discrimination and representativeness regarding grain yield of maize hybrids. Numbers 1 to 26 are intervarietal hybrids and the controls are 40 , 41 and 42 .
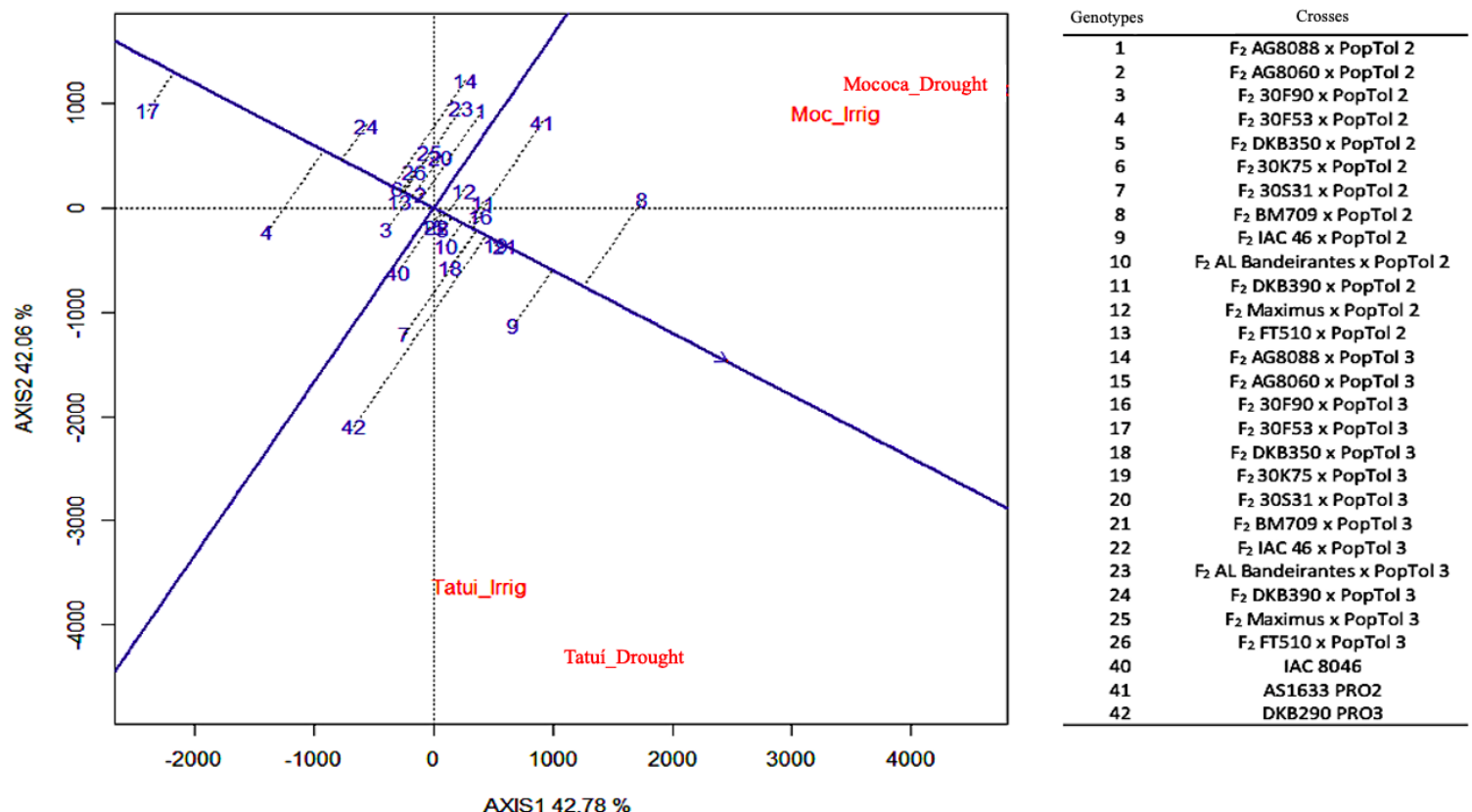

Figure 5. Graphic representation of the interrelation of the tested environments with emphasis on mean vs stability in grain yield of maize hybrids. Numbers 1 to 26 are intervarietal hybrids and the controls are 40, 41 and 42 . 
According to Yan (2011), in environments that have small vectors linked to the origin of Biplot, yield stability is high. Thus, the difference between the average yield of the genotypes was lower in the Mococa environment under adequate irrigation system for maize crop, that is, this environment contributed less to the interaction of sites $\mathrm{x}$ genotypes. The environments that most discriminated the hybrids for grain yield were Mococa and Tatuí under water deficit, being the most indicated to test the genotypes. According to Ceccarelli (1996), many improvers believe that the selection of genotypes should be conducted under ideal conditions for plant growth, aiming to maximize heritability. However, the evaluation of genotypes in adverse environments allows greater discrimination, because the selection under favorable conditions tends to cause loss in the ability to adapt to the specific condition, while the opposite is not always true.

Figure 5 illustrates the biplot that shows "Average vs Stability". The vector with the arrow passing through the origin of the chart corresponds to the axis of the average environment, and the arrow indicates the direction of higher grain yields. The vector perpendicular to the axis of the average environment is related to the stability of the hybrids; the shorter the distance of the hybrid from this vector, the greater its stability.

It can be observed that genotypes are above the overall average because they are ahead of the point of origin of the graph, represented in decreasing order of yield as: $8>9>21>19>42>7$ $>18>16>41>11>22>15>12>40$. Based on the dotted lines perpendicular to the line of the average environment, the genotypes $21\left(\mathrm{~F}_{2} \mathrm{BM} 709 \mathrm{x}\right.$ PopTol 3) and 19 (F2 30K75 x PopTol 3) can be considered the most stable and the controls AS1633 PRO2 and DKB290 PRO3, the least stable, among those with average grain yield higher than the overall average. According to Yan (2011), the term "high stability" only makes sense when it is related to the average performance, that is, the stable genotype is desirable only when it shows high average performance. Thus, genotypes 19 (F2 30K75 x PopTol 3), 21 (F2 BM709 x PopTol 3), 8 (F2 BM709 x PopTol 2) and 9 (IAC 46 x PopTol 2) can be considered superior because they show high yield, phenotypic plasticity and can be classified as tolerant to water deficit.

\section{CONCLUSIONS}

The intervarietal hybrids $\mathrm{F}_{2}$ BM709 x PopTol 2, IAC $46 \times$ PopTol 2, $F_{2} 30 \mathrm{~K} 75 \times$ PopTol 3 and $F_{2}$ BM709 $x$ PopTol 3 are considered ideotypes because they have high yield, phenotypic plasticity and tolerance to water deficit, and can be indicated for breeding programs aimed at tolerance to water deficit.

\section{REFERENCES}

AHMADIKHAH, A.; MARUFINIA, A. Effect of reduced plant height on drought tolerance in rice, 3 . Biotech, 6: 1-9, 2016.

ANJUM, S. A. et al. Drought induced changes in growth, osmolyte accumulation and antioxidant metabolism of three maize hybrids. Frontiers in Plant Science, 8: 1-12, 2017.

BERNARDO, R. Breeding for quantitative traits in plants. 2. ed., Woodbury, Minn: Stemma Press, 2010. $400 \mathrm{p}$.

CECCARELLI, S. Adaptation to low or high input cultivation. Euphytica, 92: 203-214, 1996.

DERERA, J.; TONGOONA, P.; VIVEK, B. S. Gene action controlling grain yield and secondary traits in southern African maize hybrids under drought and non-drought environments. Euphytica, 162: 411422,2008

DURAES, F. O. M. et al. Fenotipagem associada à tolerância a seca em milho para uso em melhoramento, estudos genômicos e seleção assistida por marcadores. Sete Lagoas, MG: EMBRAPA, 2004, 17 p.

EDMEADES, G. O. Progress in achieving and delivering drought tolerance in maize - An Update. Ithaca, NY: ISAAA, 2013, 44 p.

FRUTOS, E.; GALINDO, M. P.; LEIVA, V. An interactive biplot implementation in $\mathrm{R}$ for modeling genotype-by-environment interaction. Stochastic Environmental Research and Risk Assessment, 28: 1629-1641, 2014.

GUIMARÃES, P. D. S. et al. Characterizing corn hybrids (Zea mays L.) for water shortage by principal components analysis. Maydica, 59: 72-79, 2014.

KARIMIZADEH, R. et al. GGE biplot analysis of yield stability in multi-environment trials of lentil genotypes under rainfed condition. Notulae Scientia Biologicae. 5:256-262, 2013

MADABULA, F. P. et al. Rice genotypes for drought tolerance: morphological and transcriptional evaluation of auxin-related genes. Bragantia, 75: 428- 434, 2016.

MELO, A. V. et al. Desempenho agronômico de genótipos de milho submetidos ao déficit hídrico no 
sul do estado do tocantins. Revista Brasileira de Milho e Sorgo, 17: 177-189, 2018.

MORENO, A.; LUMBRERAS, V.; PAGES, M. Drought tolerance in maize. Maydica, 50: 549-558, 2005.

PIAS, O. H. C. et al. Componentes de rendimento e produtividade de híbridos de milho em função de doses de NPK e de déficit hídrico em estádios fenológicos críticos. Revista de Ciências Agroveterinárias, 16: 422-432, 2017.

RIBAUT, J. M.et al. Drought tolerance in maize. In: BENNETZEN, J.L.; HAKE, S.C. (Eds.). Handbook of Maize: Its Biology. Nova York, NY. 2009, p. 311 -314 .

SCOTT, A. J.; KNOTT, M. A cluster analysis method for grouping means in the analysis of variance. Biometrics, 30: 507-512, 1974.

SCHLICHTING, A. F. et al. Desenvolvimento do milho submetido a doses de nitrogênio e tensões de água no solo. Irriga, 19: 598-611, 2014

SSERUMAGA, J. P. et al. Grain-yield stability among tropical maize hybrids derived from doubledhaploid inbred lines under random drought stress and optimum moisture conditions. Crop and Pasture Science, 69: 691-702, 2018.

TARDIEU, F.; SIMONNEAU, T.; MULLER, B. The physiological basis of drought tolerance in crop plants: a scenario-dependent probabilistic approach. Annual review of plant biology, 69: 733-759, 2018.

THORNTHWAITE, C. W. An approach toward a rational classification of climate. New York, NY, 1948 , v. 38 , n. 1 , p. 55-94.

THORNTHWAITE, C. W.; MATHER, J. R. The water balance. Climatology, v. 8, n. 1, p. 104,1955.

TUBEROSA, R. Phenotyping for drought tolerance of crops in the genomics era. Frontiers in Physiology, 3: 1-26, 2012.

YAN, W. et al. Cultivar Evaluation and MegaEnvironment Investigation Based on the GGE Biplot. Crop Science, 40: 597-605, 2000.

YAN, W. GGE Biplot vs. AMMI Graphs for Genotype-by-Environment Data Analysis. Journal of the India Society of Agricultural Statistics, 65: 181-193, 2011.
ZIYOMO, C.; BERNARDO, R. Drought tolerance in maize: Indirect selection through secondary traits versus genome wide selection. Crop Science, 53: 1269-1275, 2013.

ZHAO, J. et al. Shoot and root traits in drought tolerant maize (Zea mays L.) hybrids. Journal of Integrative Agriculture, 17: 1093-1105, 2018. 